NASA/TM-2009-215503

\title{
Use of the X-Band Radar to Support the Detection of In-Flight Icing Hazards by the NASA Icing Remote Sensing System
}

David J. Serke and Marcia K. Politovich

The National Center for Atmospheric Research, Boulder, Colorado

Andrew L. Reehorst

Glenn Research Center, Cleveland, Ohio

Andrew Gaydos

The National Center for Atmospheric Research, Boulder, Colorado 


\section{NASA STI Program . . . in Profile}

Since its founding, NASA has been dedicated to the advancement of aeronautics and space science. The NASA Scientific and Technical Information (STI) program plays a key part in helping NASA maintain this important role.

The NASA STI Program operates under the auspices of the Agency Chief Information Officer. It collects, organizes, provides for archiving, and disseminates NASA's STI. The NASA STI program provides access to the NASA Aeronautics and Space Database and its public interface, the NASA Technical Reports Server, thus providing one of the largest collections of aeronautical and space science STI in the world. Results are published in both non-NASA channels and by NASA in the NASA STI Report Series, which includes the following report types:

- TECHNICAL PUBLICATION. Reports of completed research or a major significant phase of research that present the results of NASA programs and include extensive data or theoretical analysis. Includes compilations of significant scientific and technical data and information deemed to be of continuing reference value. NASA counterpart of peer-reviewed formal professional papers but has less stringent limitations on manuscript length and extent of graphic presentations.

- TECHNICAL MEMORANDUM. Scientific and technical findings that are preliminary or of specialized interest, e.g., quick release reports, working papers, and bibliographies that contain minimal annotation. Does not contain extensive analysis.

- CONTRACTOR REPORT. Scientific and technical findings by NASA-sponsored contractors and grantees.

- CONFERENCE PUBLICATION. Collected papers from scientific and technical conferences, symposia, seminars, or other meetings sponsored or cosponsored by NASA.

- SPECIAL PUBLICATION. Scientific, technical, or historical information from NASA programs, projects, and missions, often concerned with subjects having substantial public interest.

- TECHNICAL TRANSLATION. Englishlanguage translations of foreign scientific and technical material pertinent to NASA's mission.

Specialized services also include creating custom thesauri, building customized databases, organizing and publishing research results.

For more information about the NASA STI program, see the following:

- Access the NASA STI program home page at http://www.sti.nasa.gov

- E-mail your question via the Internet to help@ sti.nasa.gov

- Fax your question to the NASA STI Help Desk at 301-621-0134

- Telephone the NASA STI Help Desk at 301-621-0390

- Write to: NASA Center for AeroSpace Information (CASI) 7115 Standard Drive Hanover, MD 21076-1320 
NASA/TM-2009-215503

\section{Use of the X-Band Radar to Support the Detection of In-Flight Icing Hazards by the NASA Icing Remote Sensing System}

David J. Serke and Marcia K. Politovich

The National Center for Atmospheric Research, Boulder, Colorado

Andrew L. Reehorst

Glenn Research Center, Cleveland, Ohio

Andrew Gaydos

The National Center for Atmospheric Research, Boulder, Colorado

National Aeronautics and

Space Administration

Glenn Research Center

Cleveland, Ohio 44135 
Level of Review: This material has been technically reviewed by technical management.

Available from

NASA Center for Aerospace Information 7115 Standard Drive

Hanover, MD 21076-1320
National Technical Information Service 5285 Port Royal Road Springfield, VA 22161

Available electronically at http://gltrs.grc.nasa.gov 


\title{
Use of the X-Band Radar to Support the Detection of In-Flight Icing Hazards by the NASA Icing Remote Sensing System
}

\author{
David J. Serke and Marcia K. Politovich \\ The National Center for Atmospheric Research \\ Boulder, Colorado 80305 \\ Andrew L. Reehorst \\ National Aeronautics and Space Administration \\ Glenn Research Center \\ Cleveland, Ohio 44135 \\ Andrew Gaydos \\ The National Center for Atmospheric Research \\ Boulder, Colorado 80305
}

\section{Overview}

In-flight icing hazards from supercooled small drops, drizzle and freezing rain pose a threat to all aircraft. Several products have been developed to provide hazard warning of in-flight icing to the aviation community. NCAR's Current Icing Product (ref. 1) (CIP) was developed to provide a near-realtime assessment of the hazard presented by supercooled liquid water (SLW) aloft in an algorithm that combines data from satellites, the Rapid Update Cycle (RUC) model, the national two-dimensional composite of S-band NEXRAD radar reflectivity, surface observations and pilot reports (PIREPs). NIRSS (ref. 2) (fig. 1) was developed by NASA to provide a ground-based, qualitative in-flight icing hazard assessment in the airport environment with commercially available instrumentation. The system utilizes a multichannel radiometer (ref. 3), built by Radiometrics Corporation, to derive the temperature profile and integrated liquid water (ILW). NIRSS's radar is a modified airborne X-band model WU-870 made by Honeywell. The ceilometer used is a standard Vaisala CT25K Laser Ceilometer. The data from the vertically pointing ceilometer and X-band radar are only used to define the cloud bases and tops. The liquid water content (LWC) is then distributed within the cloud layers by the system software. A qualitative icing hazard profile is produced where the vertical temperature is between 0 and $-20{ }^{\circ} \mathrm{C}$ and there is measurable LWC.

None of these in-flight icing detection products currently employ radar reflectivity (REFL) fields other than to define vertical cloud boundaries, as is done in NIRSS, or to estimate the probable surface precipitation type and intensity, as is done in CIP. This may change as recent research is applied to these operational icing hazard products. Detection of SLW with radar is difficult, especially in mixed phase conditions where ice crystals can be much larger than liquid drops and thus result in higher REFL. Fabry et al. (ref. 4) discussed how in-flight icing signatures from supercooled liquid clouds present a very weak target for radars, but that that characteristic is unique at short wavelengths such as X-band. They found that SLW is evident in a vertically pointing X-band radar as REFL below $-10 \mathrm{dBZ}$ and as large vertical gradients in REFL. These gradients are caused by riming of SLW to snow, thus rapidly increasing the radar REFL below the SLW layer. Further work with McGill University's Doppler X-band (ref. 5) in wintertime, stratiform storm clouds during the AIRS-I field program found that a distinct fall velocity mode much slower than the accompanying rimed snow indicates the presence of SLW. Their work found that these clouds typically exhibited a scarcity of freezing nuclei and thus few new ice particles were formed, due to relatively mild $\left(0\right.$ to $\left.-10{ }^{\circ} \mathrm{C}\right)$ conditions at the cloud level. A study on mixed-phase clouds with a $\mathrm{K}_{\mathrm{a}}$-band radar (ref. 6) concluded that liquid-phase clouds routinely exist to much colder temperatures due to the scarcity of freezing nuclei. It is well known that general uplift associated with warm or cold fronts or low pressure troughs causes air to become saturated with respect to water, forcing 


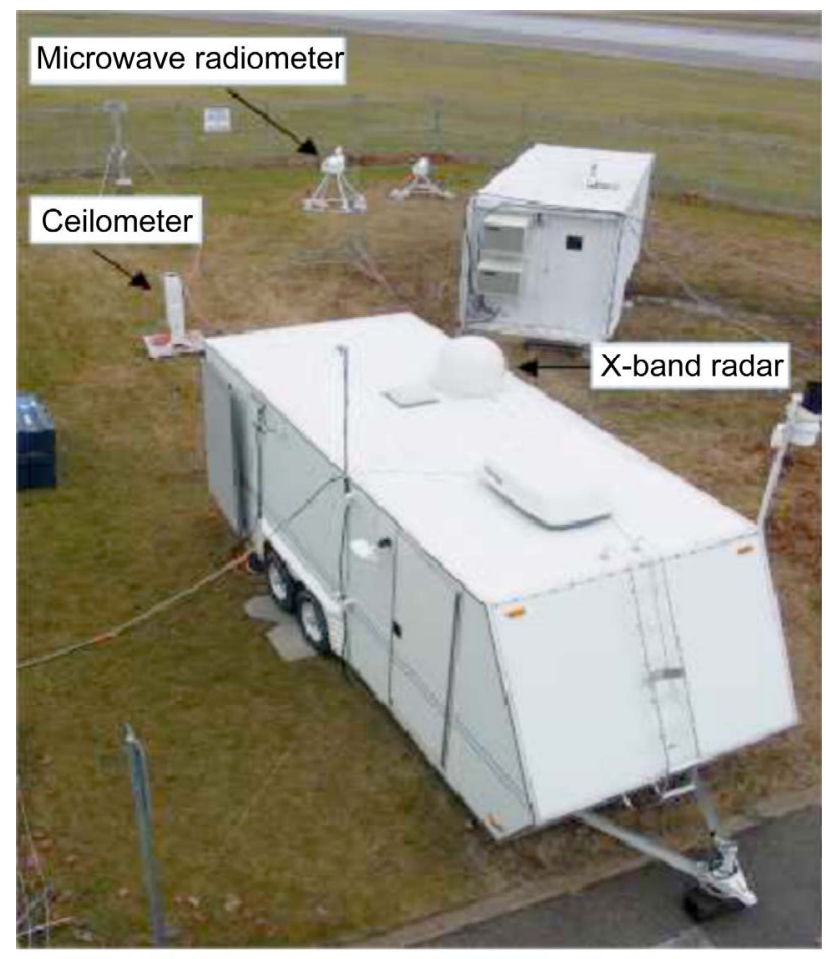

Figure 1.-NASA Icing Remote Sensing System hardware as installed for the AIRS-II field program.

water vapor to condense into water drops. If water drop generation exceeds the rate of deposition on ice crystals in a sub-freezing environment, the excess water will condense onto already existing cloud drops or form new ones.

Another recent study (ref. 7) showed that the S-band NEXRAD national radar mosaic, developed by the National Severe Storms Laboratory (NSSL), has the potential to add value in detecting in-flight icing to CIP by detecting large vertical REFL gradients within the CONUS. The possibility that the area of CIP hazard warning can be reduced in areas of horizontally and vertically-uniform REFL greater than $10 \mathrm{dBZ}$ due to the dominance of scavenging of liquid by ice crystals was also explored.

The Alliance Icing Research Studies I and II were conducted near Montreal, Canada during the winters of 1999 and 2003, respectively. The primary research aircraft were dispatched from Ottowa and ground-based remote sensing instrumentation, including NIRSS (ref. 8) and McGill University's X-band radar (fig. 2), were based at Mirabel Airport (approximately $1 \mathrm{~km}$ apart). One of the icing research aircraft was a DeHavilland DHC-6 Twin Otter which was modified for sustained flight and data collection in icing environments. The outside air temperature was measured with a Rosemount model 102AU1P probe. Microphysical probes mounted on the aircraft collected data specific to icing research. LWC was measured with a CSIRO King probe and a Nevzorov LWC probe. Particle size was measured with a Forward Scattering Spectrometer Probe (FSSP-100) and an Optical Array Probe 2DC-Gray (2DG). REFL calculated from particle distributions collected from probes aboard the research aircraft from AIRS-I (ref. 9) (fig. 3) found that a bimodal distribution for liquid and glaciated cloud phase existed over the course of the field program, with REFL less than $-10 \mathrm{dBZ}$ generally indicative of small-drop icing conditions. 


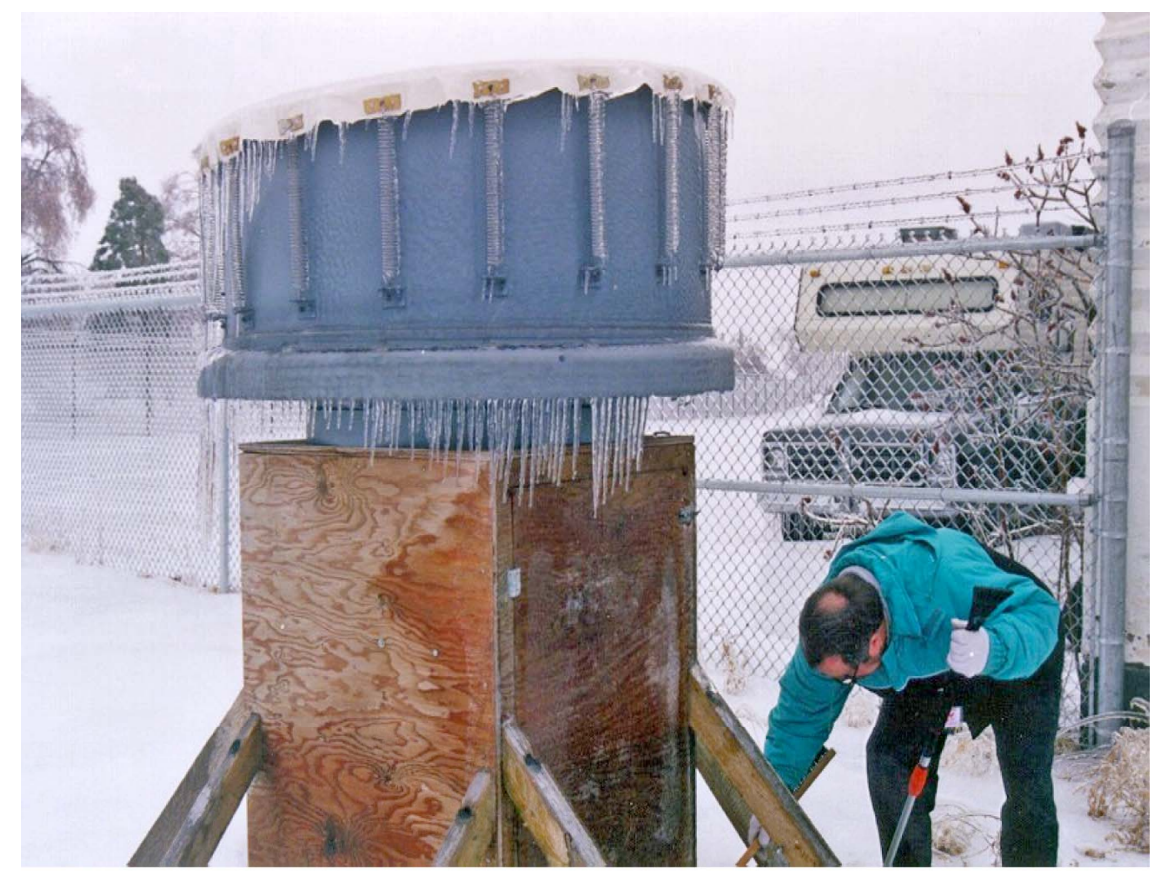

Figure 2.-McGill vertically pointing $x$-band radar as installed for the AIRS-II field program.

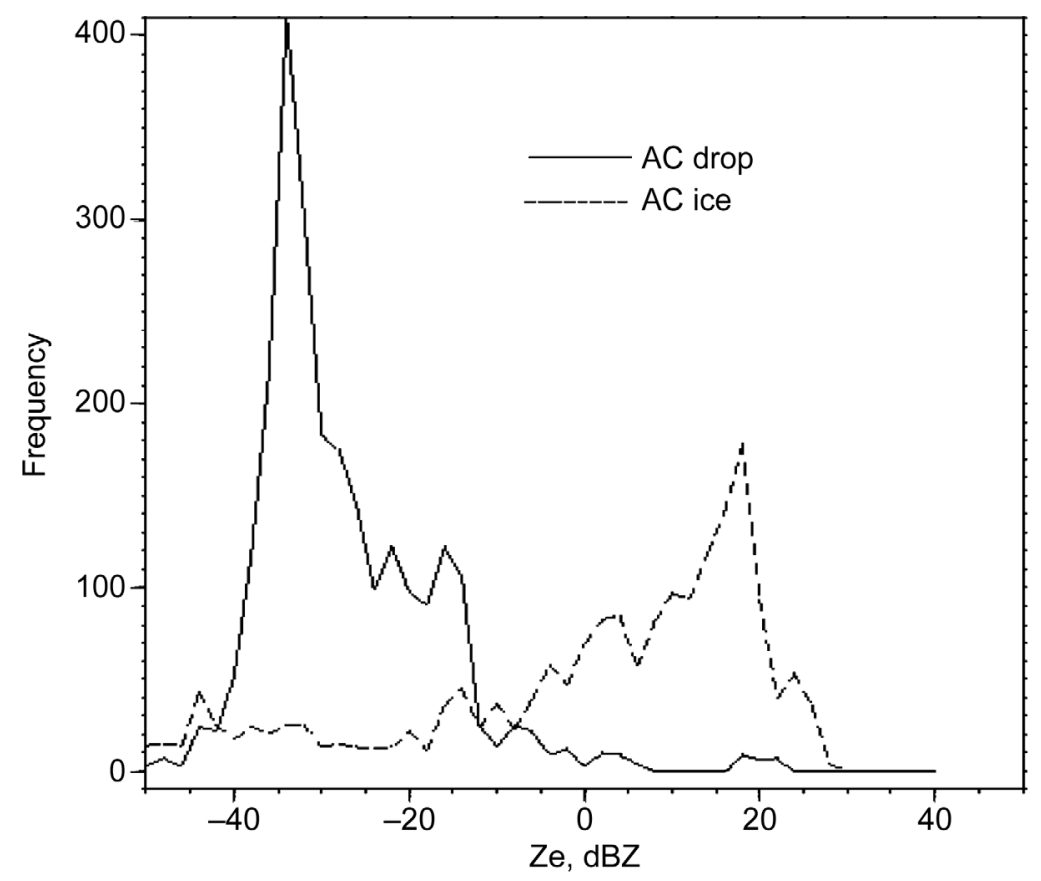

Figure 3.-Frequency of calculated reflectivities (Ze) from all AIRS-I aircraft in situ particle distributions for liquid and ice cloud phase (ref. 5). 
This study will examine X-band radar REFL profiles from NIRSS and McGill for consistency and compare them to microphysical data collected on vertical flight maneuvers by the research aircraft. Particle imagery and concentration distributions will be used to help illustrate that a qualitative small-drop in-flight icing hazard product can be derived from the vertical profile of X-band REFL. The following section presents several case studies from AIRS-II, followed by a case study from the 2005 winter icing program in Cleveland, Ohio. None of the cases show any evidence of bright band contamination.

\section{Case Studies}

\section{November 11, 2003}

The November 11, 2003, case had warm advection at $850 \mathrm{mb}$ over Mirabel ahead of a surface warm front that was positioned over Ohio and low pressure over Lake Huron (fig. 4) and subfreezing conditions from $1.6 \mathrm{~km}$ to the highest altitude sampled during the vertical flight maneuver (fig. 5(a)). Very low LWC values were measured from the aircraft (fig. 5(b)). At the time of the vertical maneuver, the X-band profile showed uniform REFL values above $10 \mathrm{dBZ}$ from 2 to above $7 \mathrm{~km}$ AGL (fig. 5(c), blue line). The McGill X-band profile (fig. 5(c), black stars) was reasonably similar to NIRSS's with no detectable directional bias. The 2DG particle image (fig. 5(d)) shows several seconds of imagery separated by time bars when the aircraft was at $2.5 \mathrm{~km}$ in altitude. The width of the plot is about $1 \mathrm{~mm}$. The image for this case shows aggregates (top and bottom), columns, plates (middle) and many smaller irregular shapes. The combined FSSP and 2DG particle concentrations at $2.5 \mathrm{~km}$ altitude (fig. 5(e)) reflect the significant population of larger ice crystals as 2DG concentrations of particles with diameters between 100 and $1000 \mu \mathrm{m}$ dropping off from $10^{7}$ to $10^{6}$ particles per $\mathrm{m}^{4}$. The high count of larger particles, low count of small particles and REFL above $10 \mathrm{dBZ}$ all point to the cloud being glaciated and the crystal population actively scavenging out any small water drops as they condense. The calculated REFL value of this distribution was about $8 \mathrm{dBZ}$.

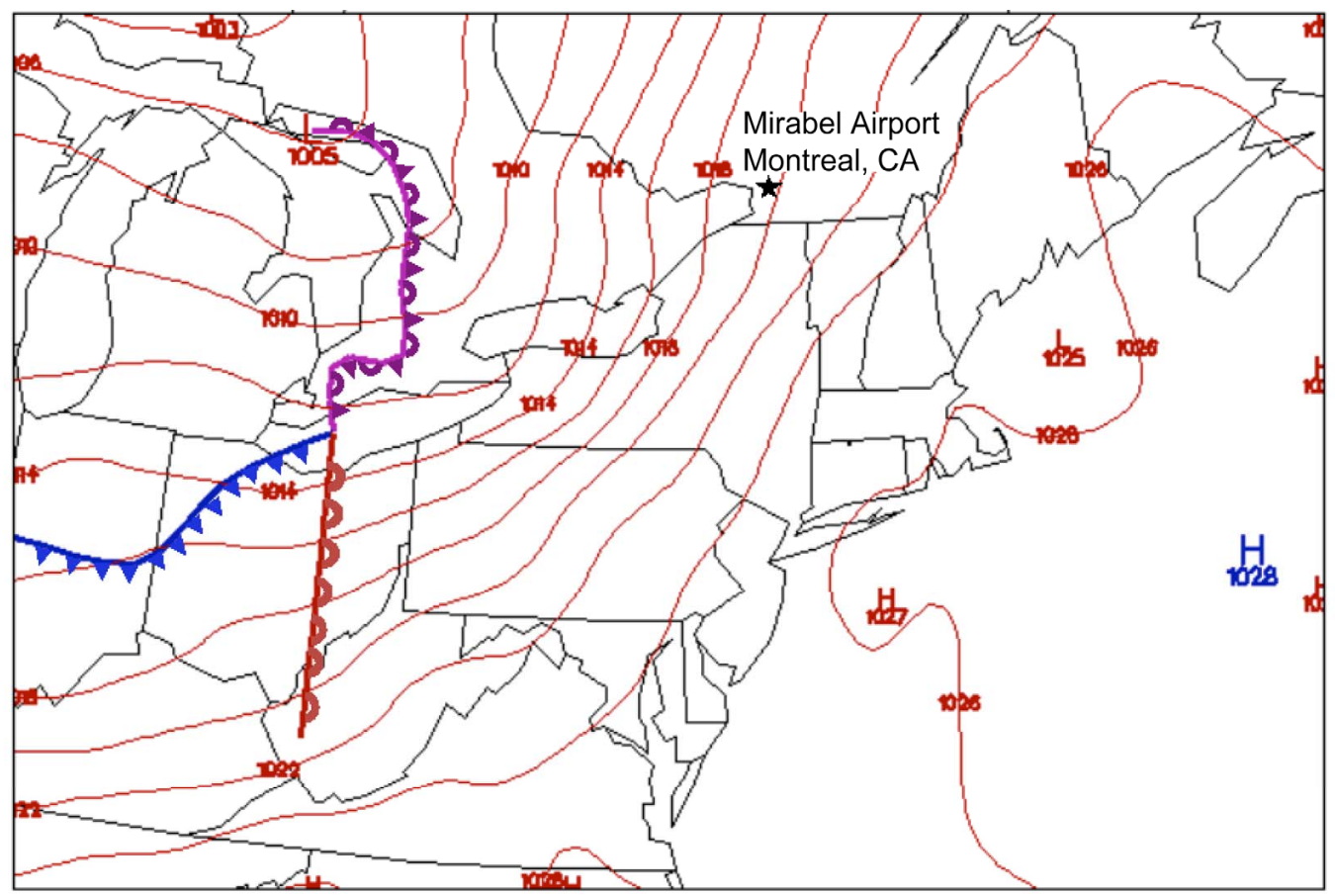

Figure 4.-Sea level pressure (red contours, $(\mathrm{mb})$ ) and NCEP frontal analysis (heavy red, blue, and magenta lines) at 15:00 UTC on November 11, 2003. 


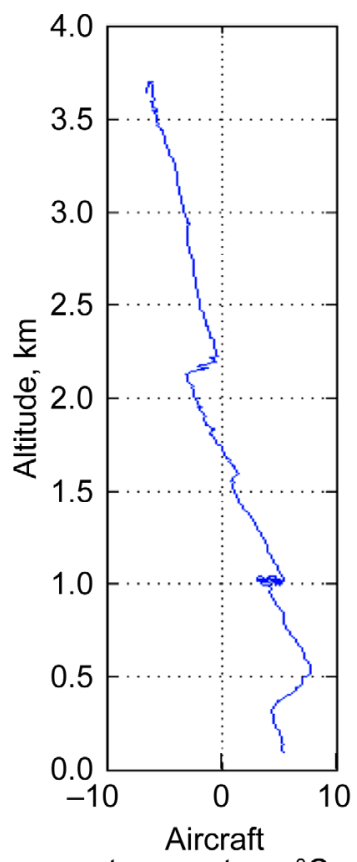

(a)
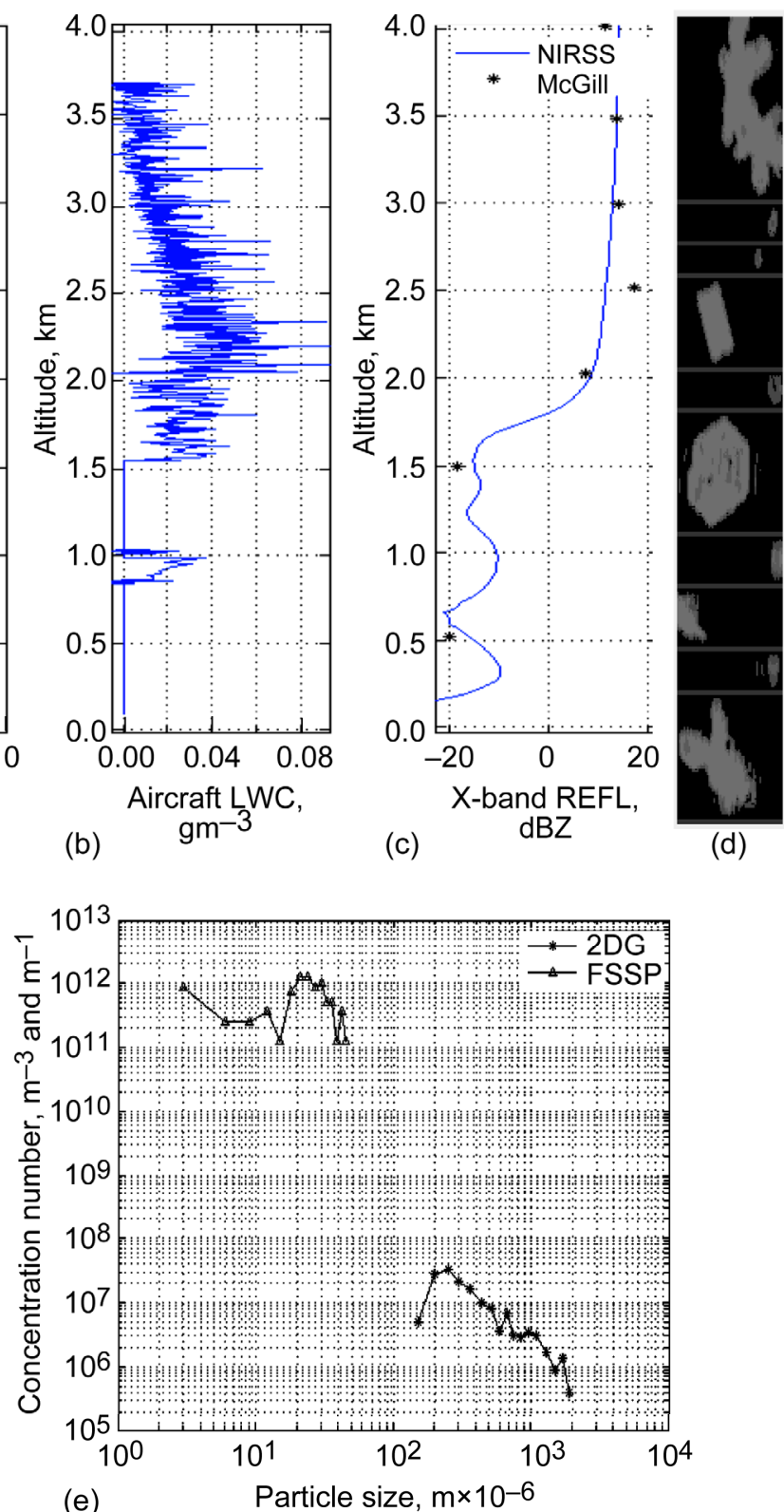

Figure 5.-(a) Twin Otter temperature, (b) CSIRO LWC, $\left(\mathrm{gm}^{-3}\right)$, (c) NIRSS and McGill X-band REFL, dBZ, (d) 2DG particle image at $2.5 \mathrm{~km}$, and (e) combined FSSP and 2DG particle distributions at $2.5 \mathrm{~km},\left(\mathrm{~m}^{-4}\right)$ at 16:45 UTC on November 11, 2003. 


\section{November 18, 2003}

The November 18, 2003, case had warm advection at $850 \mathrm{mb}$ over Mirabel ahead of a surface warm front positioned from Illinois to Kentucky and low pressure trough over from central Canada to Oklahoma (fig. 6). The temperature was below freezing at the surface (not shown) but ranged between 2 and $6{ }^{\circ} \mathrm{C}$ in the vertical flight maneuver profile (fig. 7(a)) due to an inversion. A wedge-shaped LWC profile with a maximum value above $0.4 \mathrm{gm}^{-3}$ were detected by the aircraft (fig. 7(b)). Even though icing conditions could not exist at this time due to above freezing temperatures, it is still a useful exercise to explore the microphysical characteristics of this small drop case. At the time of the vertical maneuver, the $\mathrm{X}$-band profile showed REFL values between -10 and $-20 \mathrm{dBZ}$ from the surface to the top of the liquid layer at $1.1 \mathrm{~km}$ AGL (fig. 7(c)). The REFL profile had a slight negative gradient with height through the liquid layer. The McGill X-band REFL values were mostly lower than the NIRSS X-band for this case. There were some larger liquid drops up to $200 \mu \mathrm{m}$ sensed by the 2DG (fig. 7(d)), with the characteristic donut-shaped particle shadow. The lack of shadow at the center of these larger drops is known as a Poisson spot and is caused by light diffraction. The concentration of drops (fig. 7(e)) sensed by the FSSP was two orders of magnitude larger than the November 11 glaciated case, and particles in the 2DG range were very limited.

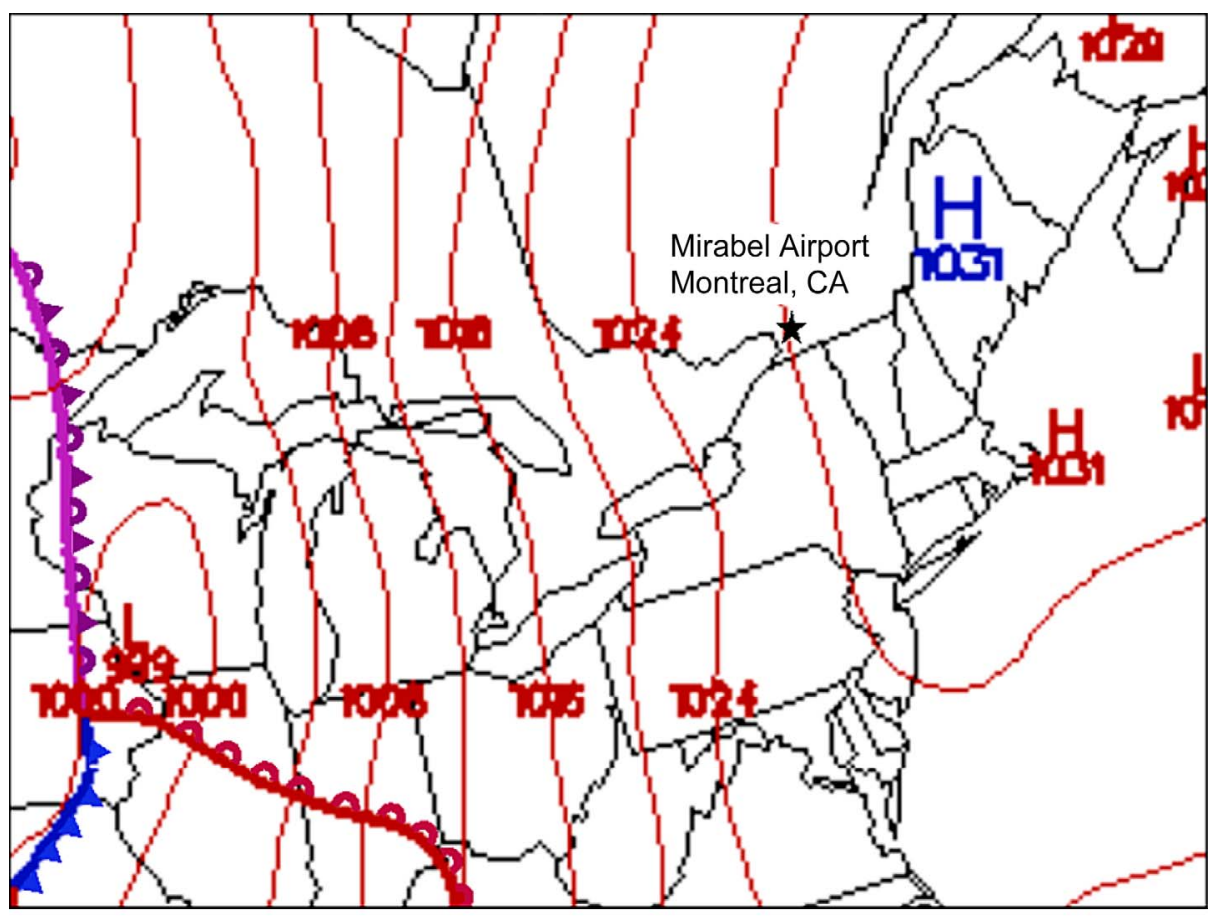

Figure 6.-Surface pressure (red contours, $(\mathrm{mb})$ ) and NCEP frontal analysis (heavy red, blue, and magenta lines) at 12:00 UTC on November 18, 2008. 


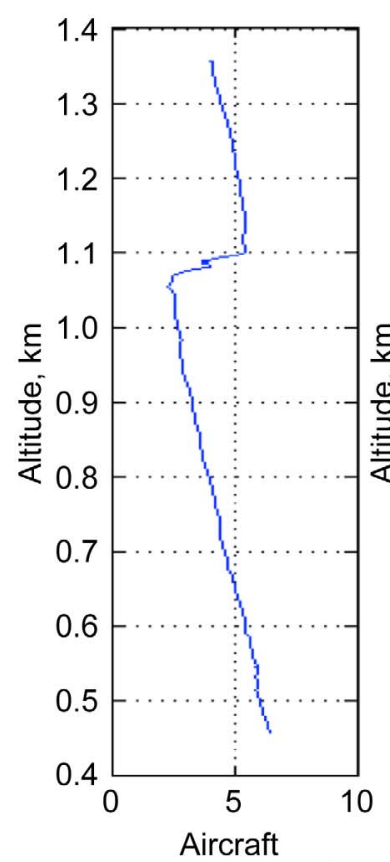

(a) temperature, ${ }^{\circ} \mathrm{C}$

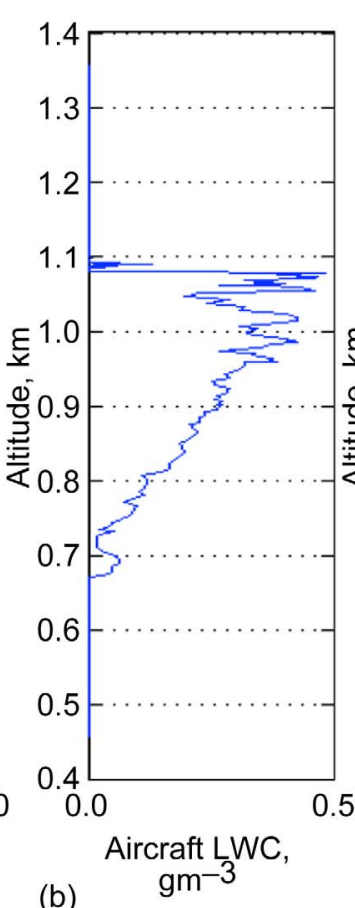

(b)

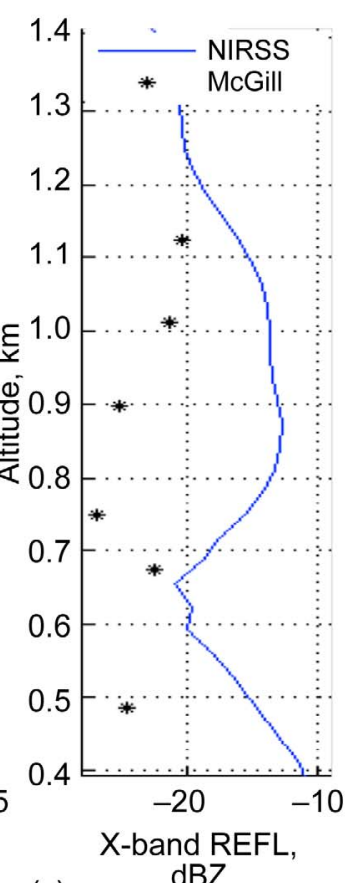

(c)

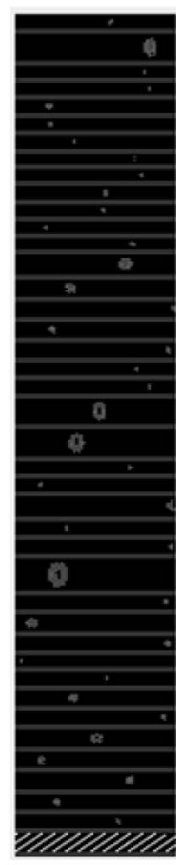

(d)

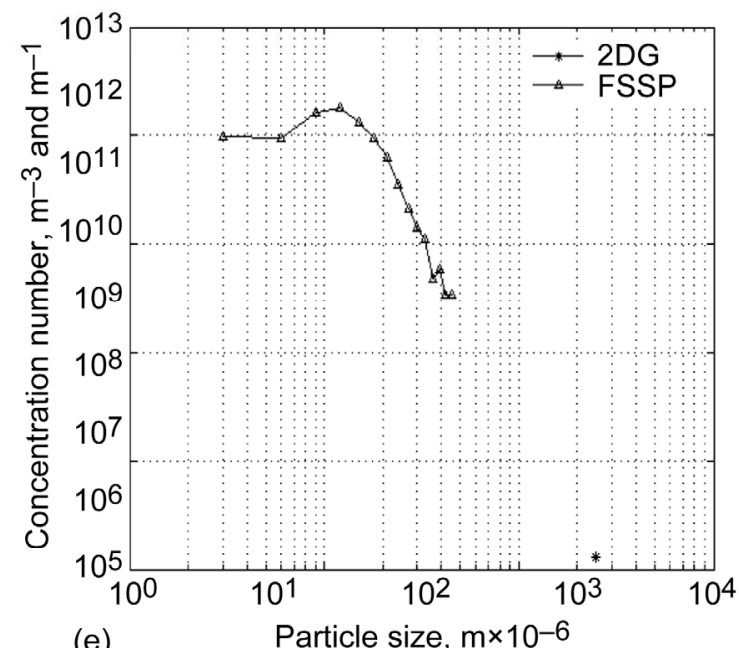

(e)

Particle size, $m \times 10^{-6}$

Figure 7.-(a) Twin Otter temperature, (b) CSIRO LWC, ( $\mathrm{gm}^{-3}$ ), (c) NIRSS and McGill X-band REFL, dBZ, (d) 2DG particle image at $1.0 \mathrm{~km}$, and (e) combined FSSP and 2DG particle distributions at $1.0 \mathrm{~km},\left(\mathrm{~m}^{-4}\right)$ at 12:40 UTC on November 18, 2003. 


\section{November 25, 2003}

The November 25, 2003, case involved a trough and cold front which had moved over Mirabel several hours before 18:00 Z (fig. 8). Cold advection through the depth of the profile led to the development of a weakly convective stratocumulus layer. The aircraft conducted a vertical spiral over Mirabel centered at 18:55 Z. The aircraft detected a wedge shaped liquid water profile, a capping temperature inversion at $1.7 \mathrm{~km}$ and subfreezing conditions down to $0.3 \mathrm{~km}$ altitude (fig. 9(a)). A thin liquid water layer between 1.3 and $1.7 \mathrm{~km}$ in altitude had a maximum LWC (fig. 9(b)) value at the top of the layer of $0.2 \mathrm{gm}^{-3}$. Over the course of the day, the radar detected the intermittent passage of the cumuliform features as REFL above $10 \mathrm{dBZ}$ (not shown). Between these crystal-dominated clouds are time periods when the REFL profile was below $-10 \mathrm{dBZ}$ (fig. 9(c)), which have been shown in previous research (ref. 5) to be associated with ice crystal-sparse conditions where supercooled liquid exist. The McGill X-band profile was reasonably similar the NIRSS for this case, with no detectable directional bias. The several second long 2DG particle image (fig. 9(d)) from $1.6 \mathrm{~km}$ altitude illustrates nonspherical ice shapes, some rimed dendrites (middle) and spherical water drops. The combined particle concentration distribution at $1.6 \mathrm{~km}$ altitude was similar to the November 18 case but with a quicker decrease in concentration of small drops above $10 \mu \mathrm{m}$ and a larger range of sizes of larger glaciated crystals in the $10^{5}$ particles per $\mathrm{m}^{4}$ range associated with the irregular and rimed dendrite ice shapes. The calculated REFL at this time was $-2 \mathrm{dBZ}$.

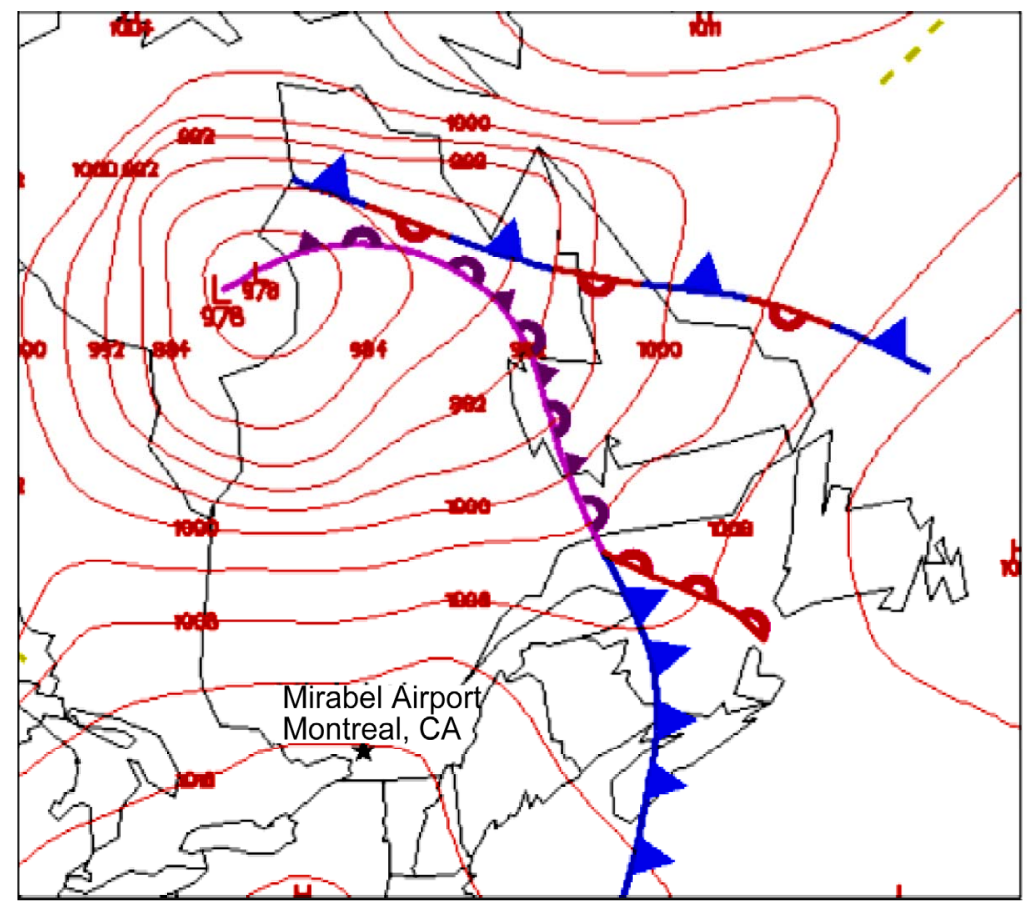

Figure 8.-Surface pressure (red contours, $(\mathrm{mb})$ ) and NCEP frontal analysis (heavy red, blue, and magenta lines) at 18:00 UTC on November 25, 2003. 


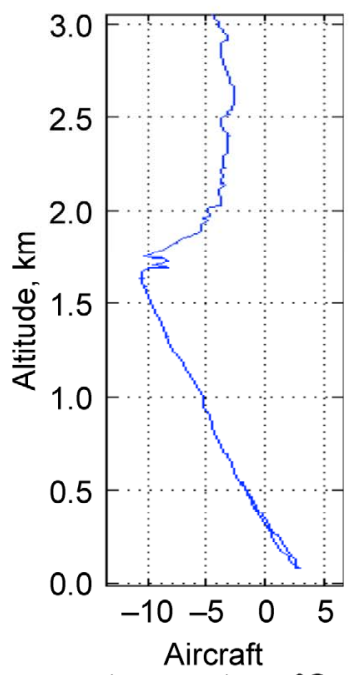

(a)

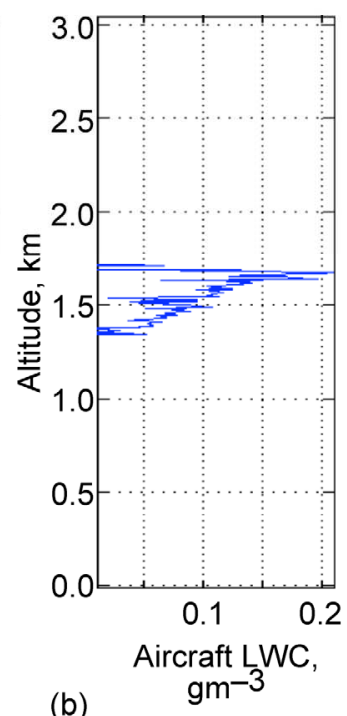

(b)

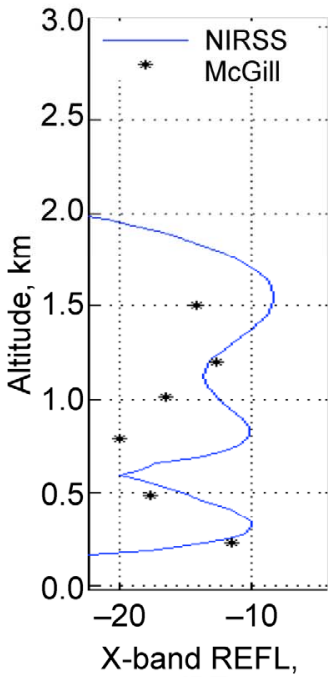

(c)

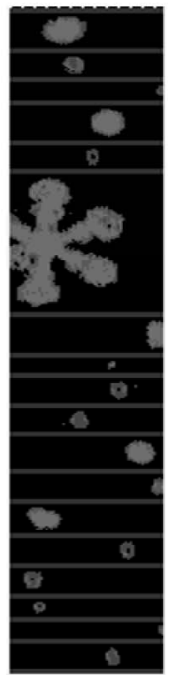

(d)

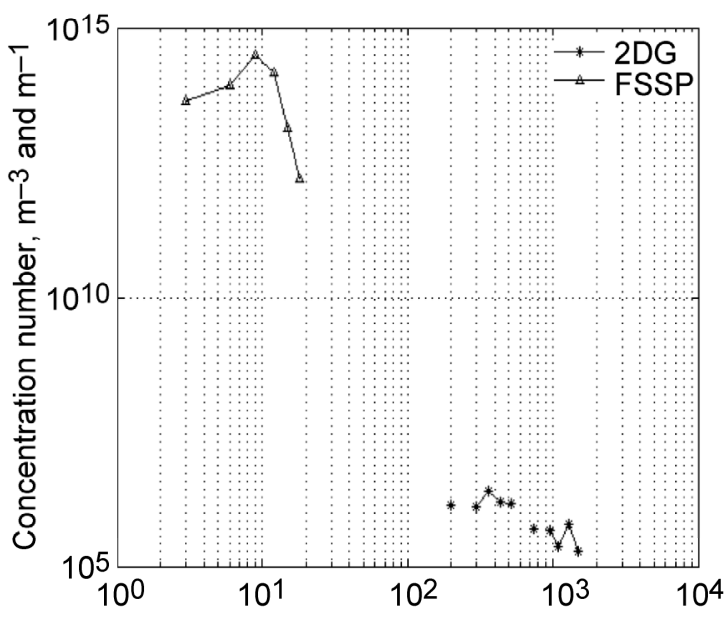

(e)

Particle size, $m \times 10^{-6}$

Figure 9.-(a) Twin Otter temperature, (b) CSIRO LWC, (gm-3), (c) NIRSS and McGill X-band REFL, dBZ, (d) 2DG particle image at $1.6 \mathrm{~km}$, and (e) combined FSSP and 2DG particle distributions at $1.6 \mathrm{~km},\left(\mathrm{~m}^{-4}\right)$ at 18:55 UTC on November 25, 2003. 


\section{December 10, 2003}

The December 10, 2003, case involved a surface low pressure over Illinois and a warm front extending from Michigan to southern Ontario, Canada. The surface chart shows warm air advection affecting the region around Mirabel (fig. 10). The aircraft conducted a vertical spiral over Mirabel centered at 16:27 UTC and detected three distinct water layers with the highest two being at or below freezing (fig. 11(a)). The maximum LWC values (fig. 11(b)) of the layers were $0.25,0.4$, and $0.45 \mathrm{gm}^{-3}$, respectively from bottom to top. REFL values within the layers (fig. 11(c)) ranged from -15 to $-27 \mathrm{dBZ}$. Each layer showed a significant negative REFL gradient with height. The McGill X-band profile was reasonably similar to the NIRSS with no detectable directional bias. Nonspherical ice shapes, rimed dendrites and spherical water drops are seen within the LWC layer at $2.6 \mathrm{~km}$ (fig. 11(d)). Rimed aggregates, smaller irregular ice shapes and water drops were detected were detected in the LWC layer at $2.1 \mathrm{~km}$ (fig. 11(e)). Aggregates, smaller irregular ice shapes, melting plates and water drops were seen in the above freezing layer at $1.2 \mathrm{~km}$ (fig. 11(f)). The distributions from the three layers decreased rapidly above $30 \mu \mathrm{m}$. Cloud-sized liquid drop concentrations below $10 \mu \mathrm{m}$ increased from the top to the middle to the bottom layer.

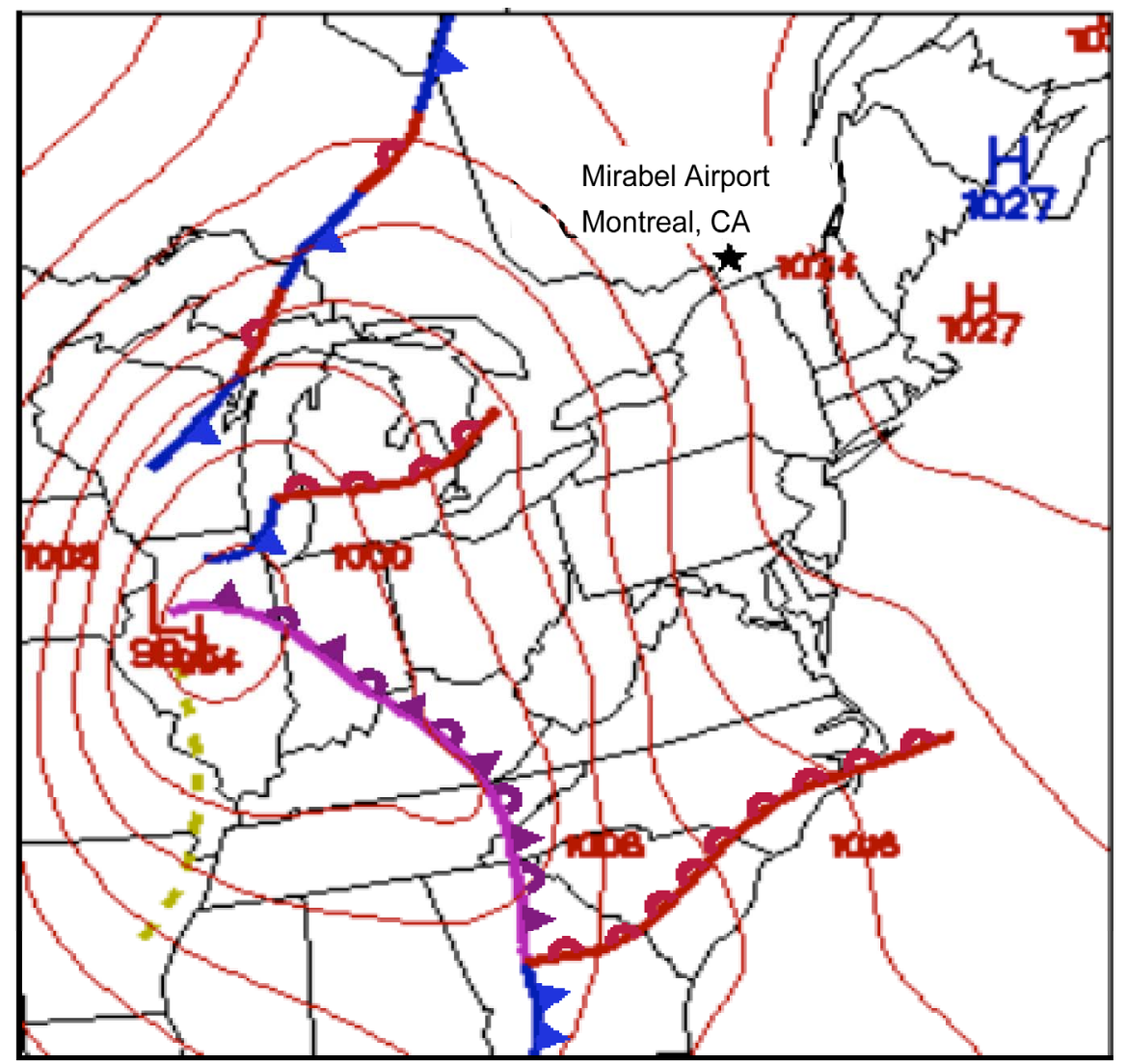

Figure 10.-Surface pressure (red contours, $(\mathrm{mb})$ ) and NCEP frontal analysis (heavy red, blue, and magenta lines) at 15:00 UTC on December 10, 2003. 


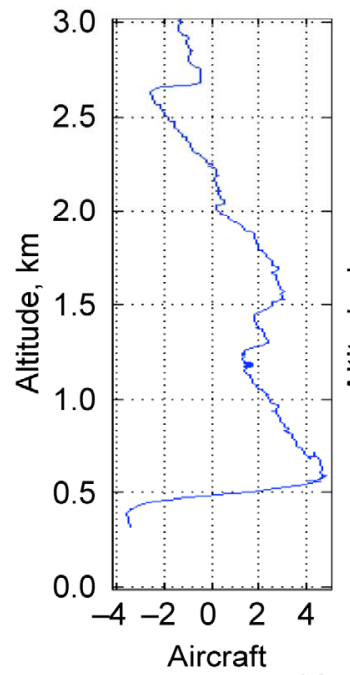

(a)

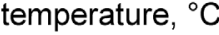

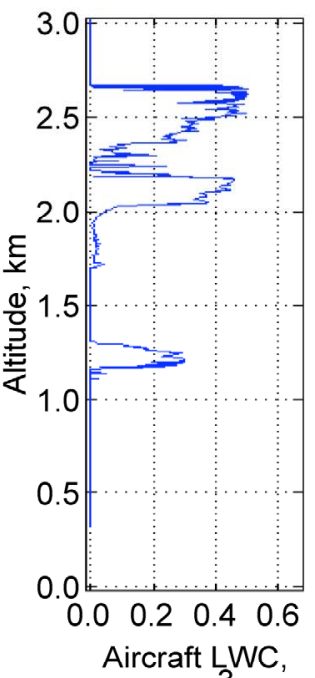

(b)

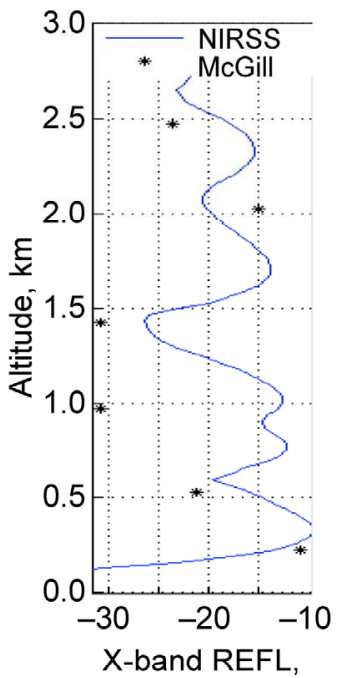

(c)

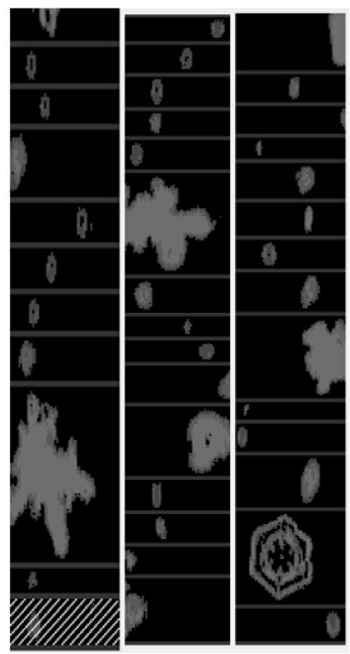

(d)

(e)

(f)

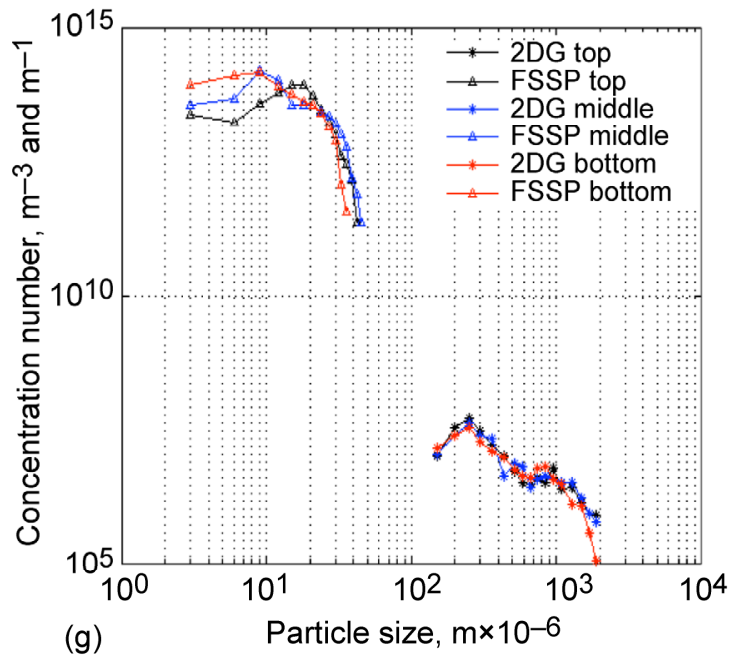

Figure 11.-(a) Twin Otter temperature, (b) CSIRO LWC, $\left(\mathrm{gm}^{-3}\right.$ ), (c) NIRSS and McGill X-band REFL, dBZ, (d) 2DG particle image at 2.6 and (e) $2.1 \mathrm{~km}$. (f) Combined FSSP and 2DG particle distributions at $2.6(\mathrm{~g})$ black, $\left(\mathrm{m}^{-4}\right), 2.1$ (blue), and 1.2 km (red) at 16:27 UTC on Decembr 10, 2003. 


\section{February 16, 2005}

The February 16, 2005, case involved a surface low pressure over northeastern Pennsylvania and a cold front that had previously passed over northern Ohio now extending southwestward over West Virginia. The $850 \mathrm{mb}$ map shows cold air advection affecting the region around Cleveland's Hopkins International Airport (fig. 12). The aircraft collected vertical profile data on takeoff centered at 15:10 UTC and on a missed approach centered on 17:15 UTC.

Temperatures were subfreezing (fig. 13(a)) from the surface through the maximum altitude of the aircraft's vertical maneuver. The aircraft detected a wedge-shaped SLW profile from 0.6 to $1.7 \mathrm{~km}$ in altitude at 15:10 UTC (fig. 13(b)). Maximum LWC values at several heights reached $0.4 \mathrm{gm}^{-3}$. REFL values were $-20 \mathrm{dBZ}$ at the bottom of the layer and dropped to the minimum detectable value of $-35 \mathrm{dBZ}$ near $1.2 \mathrm{~km}$ (fig. 13(c)). The large REFL gradient (ref. 4) was likely due to the effects of diffusional growth and cloud drop accretion decreasing with height. The particle imagery at $1.6 \mathrm{~km}$ (fig. 13(d)) shows mostly very small liquid drops with virtually no ice particles. Imagery from $0.8 \mathrm{~km}$ (fig. 13(e)) shows mostly small drops and a $400 \mu \mathrm{m}$ rimed aggregate. The combined particle concentration distribution (fig. 13(f)) at $1.6 \mathrm{~km}$ (blue line) depicts a wide, uniform population of supercooled cloud water drops up to $30 \mu \mathrm{m}$ in diameter. The rapid decrease in concentrations above $100 \mu \mathrm{m}$ is due to the presence of the few larger supercooled liquid drops and nearly complete absence of more irregularly shaped glaciated particles. At $0.8 \mathrm{~km}$, there is a more pronounced peak in population at $10 \mu \mathrm{m}$, and a more rapid decrease after $10 \mu \mathrm{m}$. The $0.8 \mathrm{~km}$ distribution had some particles above $300 \mu \mathrm{m}$, whereas the distribution at $1.6 \mathrm{~km}$ ended at $300 \mu \mathrm{m}$. A theoretical REFL value of $-23 \mathrm{dBZ}$ results from the particle distribution from $1.5 \mathrm{~km}$ and a value of $-10 \mathrm{dBZ}$ from the distribution from $0.8 \mathrm{~km}$.

By 17:15 UTC, the temperature profile had cooled slightly due to continued cold advection (fig. 14(a)) and the SLW had decreased to two layers (fig. 14(b)) at 0.6 and $0.8 \mathrm{~km}$ with maximum values above $0.1 \mathrm{gm}^{-3}$. Some LWC amounts were also located above $1.5 \mathrm{~km}$ but the aircraft did not sample much above that altitude. REFL values (fig. 14(c)) decreased from $-18 \mathrm{dBZ}$ just below the primary SLW layers to $-23 \mathrm{dBZ}$ just above them. It is unknown whether the negative vertical REFL gradient from 0.6 to $0.8 \mathrm{~km}$ is significant or a variation due to noise in the radar return. The combined particle concentration distribution shows no detected particle population in the 2DG range (fig. 14(d)), so no particle images are available. The theoretical REFL for the particle distribution at $0.8 \mathrm{~km}$ is $-29 \mathrm{dBZ}$.

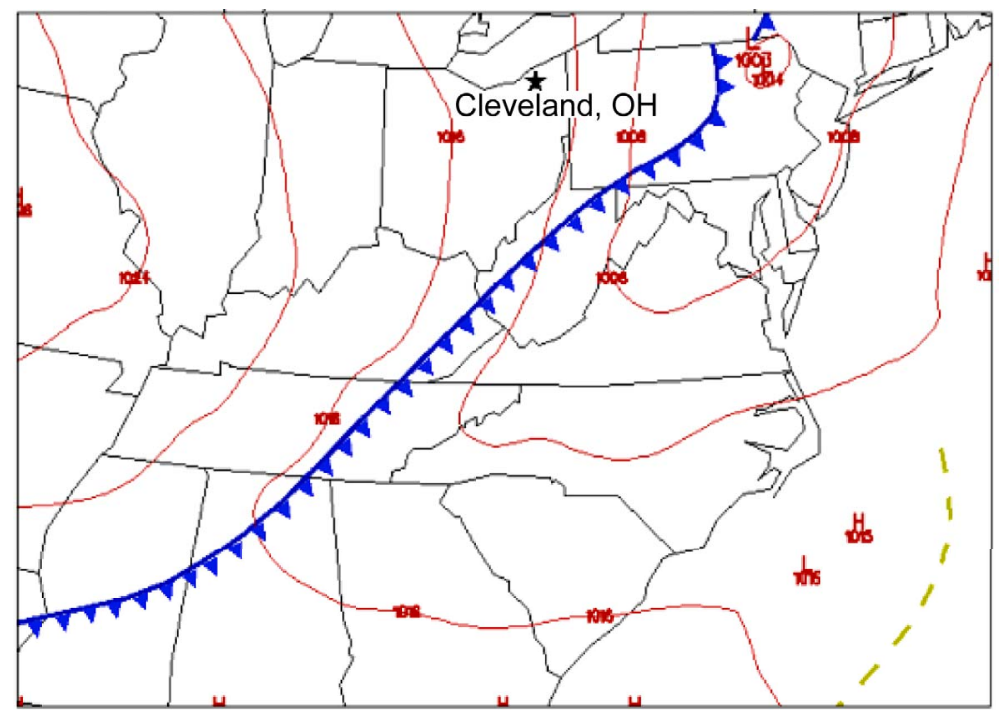

Figure 12.-Surface pressure (red contours, $(\mathrm{mb})$ ) and NCEP frontal analysis (heavy blue line) at 15:00 UTC on February 16, 2005. 


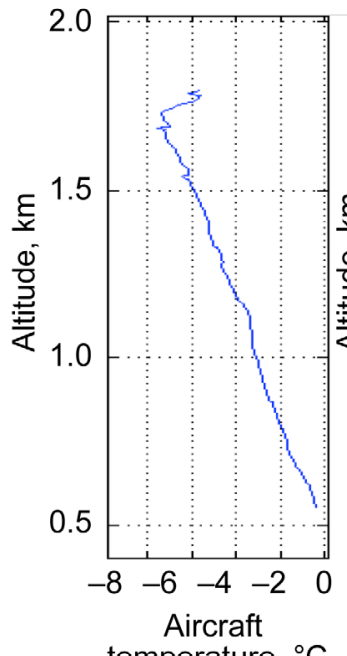

(a)

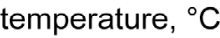

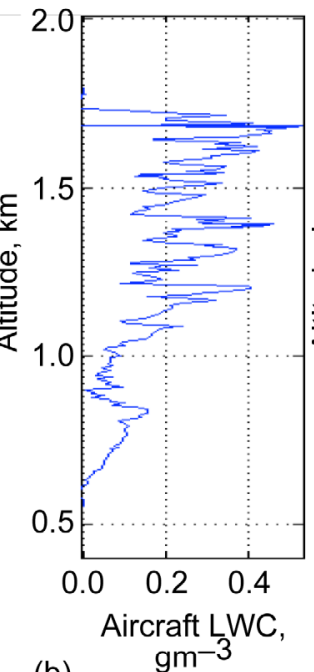

(b)

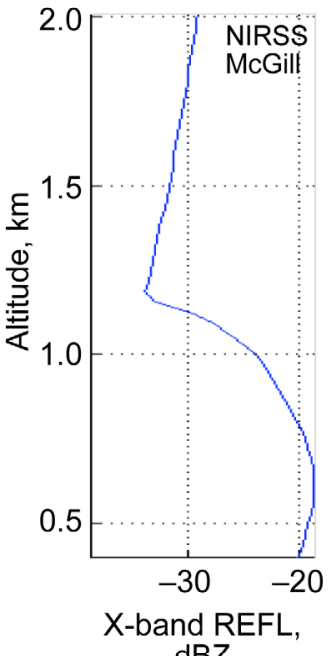

(c)

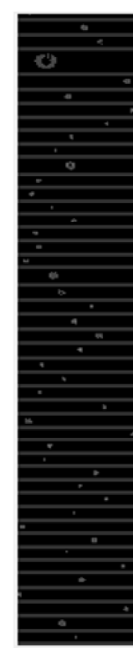

(d)

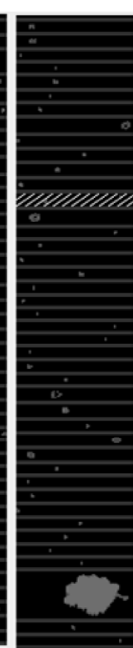

(e)

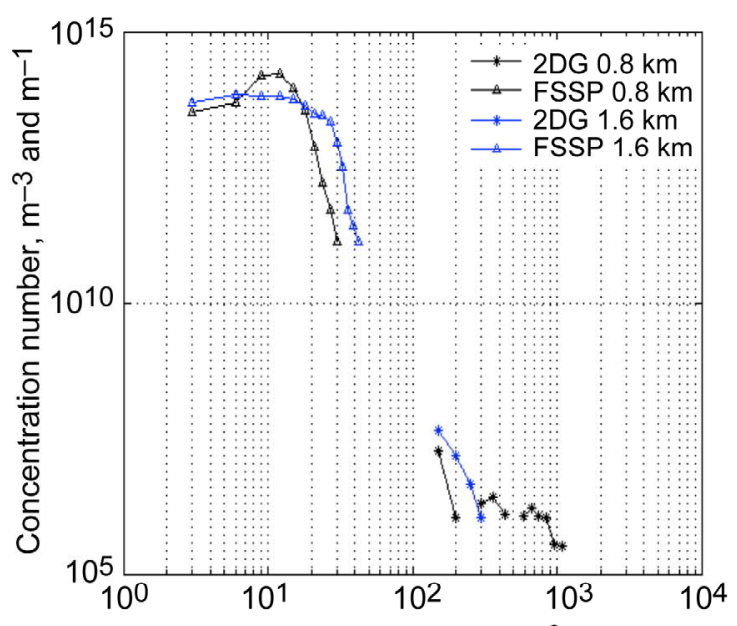

(f)

Particle size, $m \times 10^{-6}$

Figure 13.-(a) Twin Otter temperature, (b) CSIRO LWC, $\left(\mathrm{gm}^{-3}\right)$, (c) NIRSS and McGill X-band REFL, dBZ, (d) 2DG particle imagery at 1.6 and (e) $0.8 \mathrm{~km}$. (f) Combined FSSP and 2DG particle distributions at $1.6 \mathrm{~km}$, (f) blue, $\left(\mathrm{m}^{-4}\right)$ and $0.8 \mathrm{~km}$ (black) at 15:10 UTC on February 16, 2005. 


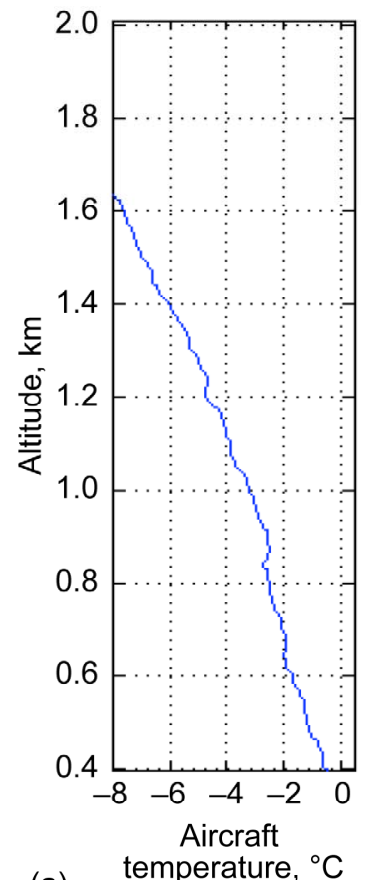

(a)

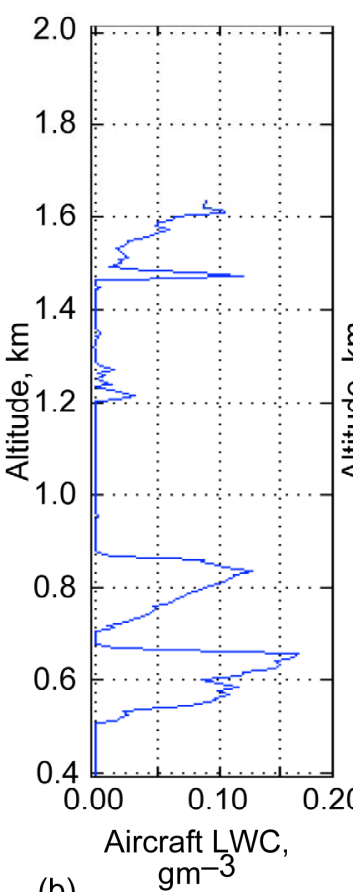

(b)

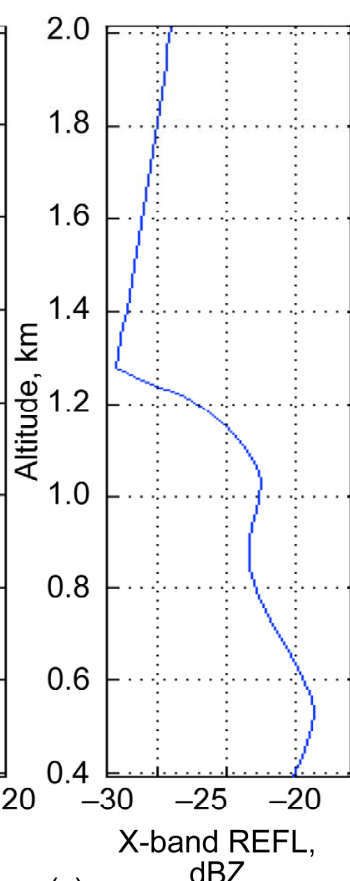

(c)

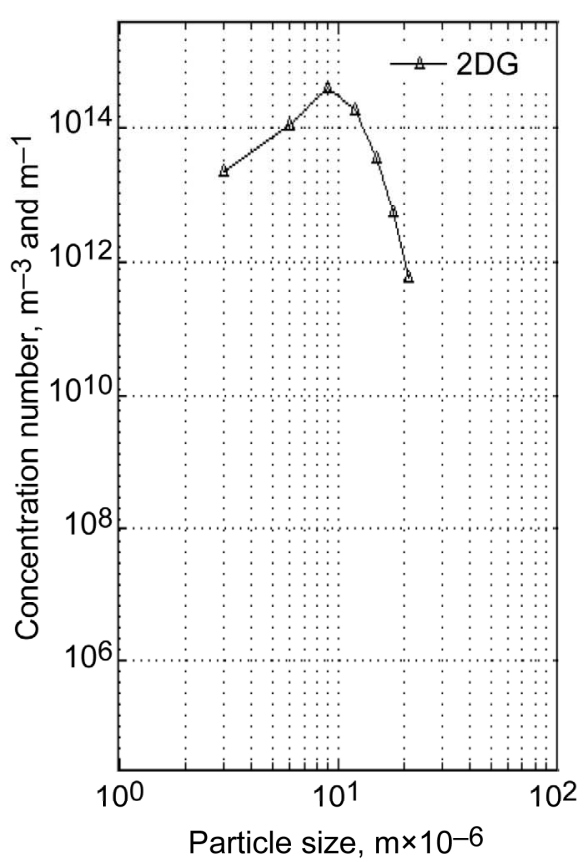

(d)

Figure 14.-(a) Twin Otter temperature, (b) CSIRO LWC, $\left(\mathrm{gm}^{-3}\right.$ ), (c) NIRSS and McGill X-band REFL (dBZ), and (d) combined FSSP and 2DG particle distributions at $0.8 \mathrm{~km},\left(\mathrm{~m}^{-4}\right)$ at 17:15 UTC on February 16, 2005.

\section{Conclusion}

Since the McGill X-band radar was calibrated before the field program but had up to a 15-min. time recording error in an unknown direction (personal communication with I. Zawadzki) and a 1-km horizontal separation from the NIRSS radar, a precise comparison between the two radars was not possible. The NIRSS X-band REFL profiles agreed reasonably well with McGill's X-band profiles. No clear calibration bias in the NIRSS radar was detectable with the limited number of cases examined. This leads to the conclusion that the off-the-shelf X-band radar was good enough to detect cloud levels and small-drop icing conditions over time without significant calibration biases effecting the measured REFL field.

The cases examined for this study represent mostly small drop (MVD less than $50 \mu \mathrm{m}$ ) icing scenarios. No large concentration of ice crystal populations were reported in any case study except November 11,2003. This particular case study showed that profile times that had large populations of larger crystals and REFLS above $10 \mathrm{dBZ}$ had negligible LWC. Any LWC that condensed into drops was quickly scavenged out by the large crystals by deposition or accretion processes. Case studies with significant SLW in one or more layers had REFL that were between the minimum detectable REFL value and $-10 \mathrm{dBZ}$. The case studies showed that an operational system like NIRSS could provide a qualitative in-flight icing warning for X-band REFL profiles that were uniformly low. Negative vertical gradients of REFL with height occurred in several of the cases where the small drop SLW layers existed. It is not understood at this time what caused these gradients. These wintertime cases all had weak lift associated with pre-warm frontal, post-cold frontal or trough passage. The lift led to saturation with respect to liquid water and generation of water vapor in excess of that being deposited on the sparse population of small ice crystals (as evidenced by low REFL, low 2DG counts and no precipitation). The excess water vapor led to the condensation of supercooled liquid cloud which could be detected by NIRSS's X-band as REFL profiles less than perhaps $-10 \mathrm{dBZ}$. 
Future work will include a module in the NIRSS software to create an icing hazard field based solely on times when REFL are uniformly less than about $-10 \mathrm{dBZ}$ and/or sharp vertical REFL gradients exist. This hazard field should be validated against further cases when positive PIREPs, research flight data, NIRSS radiometer and icing severity data exist. The addition of Doppler capabilities to the NIRSS vertically pointing radar would enhance NIRSS's in-flight icing hazard detection by allowing for the discrimination between SLW, pristine snow and rimed snow particle populations.

\section{References}

1. Bernstein, B., McDonough, F., Politovich, M., Brown, B., Ratvasky, T., Miller, D., Wolff, C., and Cunning G., "Current Icing Potential: Algorithm Description and Comparison to Aircraft Observations," Journal of Applied Meteorology, 44, pp. 969-986, 2005.

2. Reehorst, A., Politovich, M., Zednik, S., Isaac, G., and Cober, S., "Progress in the Development of Practical Remote Detection of Icing Conditions," NASA/TM-2006-214242, 2006.

3. Solheim, F., Godwin, J., Westwater, E., Han, Y., Keihm, S., Marsh, K., and Ware, R., "Radiometric Profiling of Temperature, Water Vapor and Cloud Liquid Water Using Various Inversion Methods," Radio Science, 33, pp. 393-404, 1998.

4. Fabry, F., Zawadzki, I., Bell, C., and Cote, C., "Doppler Radar Signatures of In-Flight Icing Conditions," 30th International Conference on Radar Meteorology, Munich, Germany, July 19-24, 2001.

5. Zawadzki, I., Fabry F., and Szyrmer, W., "Observations of Supercooled Water and of Secondary Ice Generation by a Vertically Pointing X-Band Doppler Radar,” Atmospheric Research, 59-60, 343359, 2001.

6. Verlinde, J., Harrington, J., McFarquhar, G., Yannuzzi, V., Avramov, A., Greenberg, S., Johnson, N., Zhang, G., Poellot, M., Mather, J., Turner, D., Eloranta, E., Zak, B., Prenni, A., Daniel, J., Kok, G., Tobin, D., Holz, R., Sassen, K., Spangenberg, D., Minnis, P., Tooman, T., Ivey, M., Richardson, S., Bahrmann, C., Shupe, M., DeMott, P., Heymsfield, A., and Schofield R., "The Mixed-Phase Artic Cloud Experiment," Bulletin of the American Meteorological Society, 88, pp. 205-221, 2007.

7. Serke, D.J., McDonough, F., and Politovich, M., "Analysis of 3-D NEXRAD Mosaic Reflectivity Data Colocated With Research Aircraft and Satellite Data: Implications on In-Flight Icing," AMS, New Orleans, LA, January 20-24, 2008.

8. Reehorst, A.L., Brinker, D.J., Ratvasky, T.P., "NASA Icing Remote Sensing System: comparisons from AIRS-II," NASA/TM-2005-213592, 2005.

9. Hudak, D., Currie, B., Rodriguez, P., Cober, S.G., Zawadzki, I., Isaac, G.A., and Wolde, M., “Cloud Phase Detection in Winter Stratiform Clouds Using Polarimetric Doppler Radar," Proceedings of ERAD, pp. 90-94, 2002. 


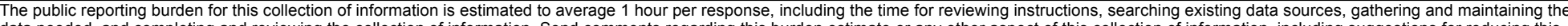

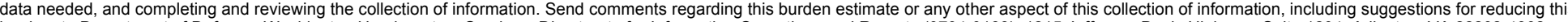

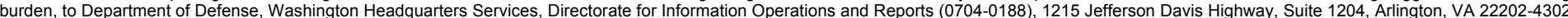

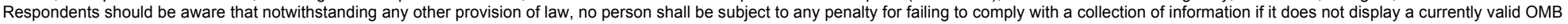
control number.

PLEASE DO NOT RETURN YOUR FORM TO THE ABOVE ADDRESS
1. REPORT DATE (DD-MM-YYYY)
2. REPORT TYPE
3. DATES COVERED (From - To)

01-03-2009

Technical Memorandum

\section{TITLE AND SUBTITLE}

Use of the X-Band Radar to Support the Detection of In-Flight Icing Hazards by the NASA

Icing Remote Sensing System

\section{5a. CONTRACT NUMBER}

5b. GRANT NUMBER

5c. PROGRAM ELEMENT NUMBER

\section{AUTHOR(S)}

Serke, David, J.; Politovich, Marcia, K.; Reehorst, Andrew, L.; Gaydos, Andrew

\section{5d. PROJECT NUMBER}

5e. TASK NUMBER

5f. WORK UNIT NUMBER

WBS 609866.02.07.03.04

\section{PERFORMING ORGANIZATION NAME(S) AND ADDRESS(ES)}

National Aeronautics and Space Administration

John H. Glenn Research Center at Lewis Field

8. PERFORMING ORGANIZATION

REPORT NUMBER

Cleveland, Ohio 44135-3191

E-16691

\section{SPONSORING/MONITORING AGENCY NAME(S) AND ADDRESS(ES)}

National Aeronautics and Space Administration

Washington, DC 20546-0001

\section{SPONSORING/MONITORS ACRONYM(S) \\ NASA \\ 11. SPONSORING/MONITORING REPORT NUMBER \\ NASA/TM-2009-215503}

\section{DISTRIBUTION/AVAILABILITY STATEMENT}

Unclassified-Unlimited

Subject Categories: 03, 35, and 47

Available electronically at http://gltrs.grc.nasa.gov

This publication is available from the NASA Center for AeroSpace Information, 301-621-0390

\section{SUPPLEMENTARY NOTES}

\section{ABSTRACT}

The Alliance Icing Research Study-II (AIRS-II) field program was conducted near Montreal, Canada during the winter of 2003. The NASA Icing Remote Detection System (NIRSS) was deployed to detect in-flight icing hazards and consisted of a vertically pointing multichannel radiometer, a ceilometer and an x-band cloud radar. The radiometer was used to derive atmospheric temperature soundings and integrated liquid water, while the ceilometer and radar were used only to define cloud boundaries. The purpose of this study is to show that the radar reflectivity profiles from AIRS-II case studies could be used to provide a qualitative icing hazard.

\section{SUBJECT TERMS}

Aircraft icing; Meteorological radar; Microwave radiometers; Optical radar; Multisensor fusion; Aircraft hazards; Cloud physics

\begin{tabular}{|c|c|c|c|c|}
\hline \multicolumn{3}{|c|}{ 16. SECURITY CLASSIFICATION OF: } & \multirow{2}{*}{$\begin{array}{l}\text { 17. LIMITATION OF } \\
\text { ABSTRACT }\end{array}$} & \multirow{2}{*}{$\begin{array}{l}\text { 18. NUMBER } \\
\text { OF } \\
\text { PAGES } \\
21\end{array}$} \\
\hline $\begin{array}{l}\text { a. REPORT } \\
\text { U }\end{array}$ & $\begin{array}{l}\text { b. ABSTRACT } \\
U\end{array}$ & $\begin{array}{l}\text { c. THIS } \\
\text { PAGE } \\
\text { U }\end{array}$ & & \\
\hline
\end{tabular}



